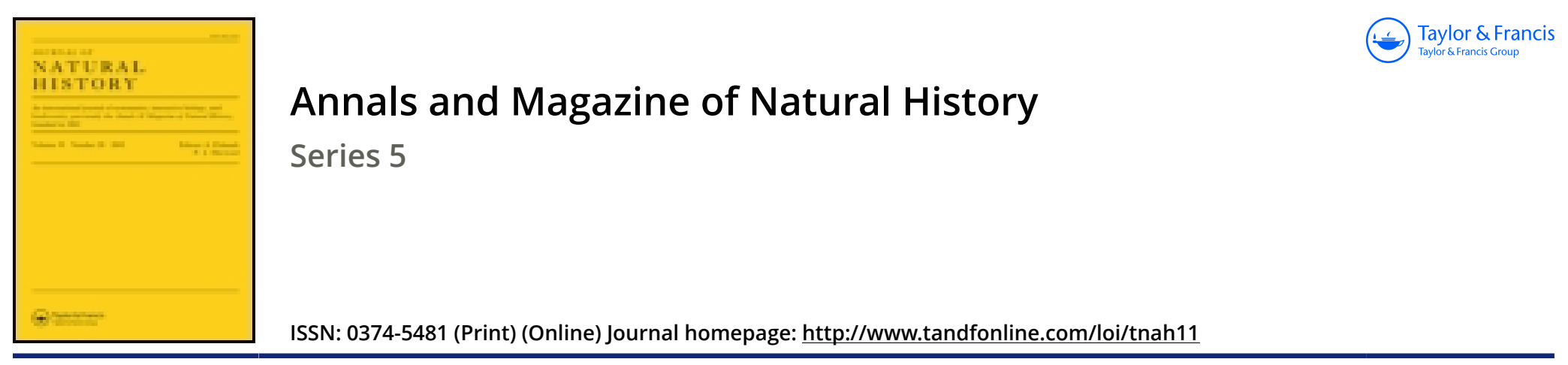

\title{
VIII.-Note on the detection of Polycystina within the hermetically closed cavities of certain nodular flints
}

\section{Surgeon-Major Wallich M.D.}

To cite this article: Surgeon-Major Wallich M.D. (1883) VIII.-Wote on the detection of Polycystina within the hermetically closed cavities of certain nodular flints, Annals and Magazine of Natural History, 12:67, 52-53, DOI: 10.1080/00222938309459573

To link to this article: http://dx.doi.org/10.1080/00222938309459573

曲 Published online: 07 Oct 2009.

Submit your article to this journal $\pi$

Џll Article views: 3

Q View related articles $\sqsubset$ 
T. hecabe; they may, however, be hybrids between the two species.

\section{Terias hecabe.}

Papilio hecabe, Linnæus, Mus. Lud. Ulr. p. 249 (1764).

N. Formosa.

\section{Ganoris gliciria.}

Papilio gliciria, Cramer, Pap. Exut. ii. pl. 171. E, F (1779).

‥ N. Formosa.

10. Ornithoptera rhadamanthus.

Ornithoptera rhadlamanthus, Boisduval, Sp. Gén. Lép. i. p. 180). n. 8 (1836).

․ S. Formosa.

Owing to press of work it has been necessary to defer giving an account of the moths in this collection.

VIII.-Note on the Detection of Polycystina within the hermetically closed Cavities of certain Nodular Flints. By Surgeon-Major WALLICH, M.D.

IN continuation of my previous papers on the "Origin and Mode of Formation of the Cretaceous Flints"*, I beg to announce the discovery by me, last summer, of a number of well-marked Polycystina amongst the loose fossilized contents of nodular flints obtained from the Surrey gravel-pits. In common with other observers I have often noticed minute objects in flint sections, which are, in all probability, the remains of these organisms; but in no instance were the appearances revealed by the microscope sufficiently distinct to place their identity beyond question. In the case of the structures now under notice there can be no doubt of the kind; and we are thus furnished with another interesting link in the chain of evidence which goes to prove the general lithological identity of the chalk with recent deep-sea calcareous deposits.

The genera of Polycystina met with in the nodular cavities are, for the most part, Astromma, Haliomma (both dis-

* Quart. Journ. Geol. Soc. for Feb. 1880, and Ann. \& Mag. Nat. Hist. for Feb., March, and July 1881. 
coidal and spherical), and Podocyrtis. A few specimens of well-marked fossilized Dictyochidæ also occur. Both the Polycystina and the Dictyochidæ, as well as the mass of the loose granular material associated with them in the same flintcavities, are more or less metamorphosed by a slight admixture of peroxide of iron and calcite, the former substance having imparted to the entire structures a bright reddish hue.

Through the courtesy of Prof. T. G. Bonney, F.R.S., I have been enabled to examine a slide of "diaspro" containing Polycystina. These, however, exhibit somewhat less of the characteristic structure of the organisms, owing, no doubt, to their having become fossilized under less favourable conditions than those which existed in the hermetically closed flint-cavities. In both cases the polariscope shows the silica to have been partially replaced by calcite.

I have likewise found in material obtained from hermetically closed flint-cavities, by far the most perfectly preserved Foraminifera I have ever seen, the shell-structure and chambers, with every minutest detail of tubular structure, having been converted into chalcedony - the whole mass by reflected light presenting a beautifully whitish-blue opalescent appearance, whilst by transmitted light it exhibits a rich transparent burntsienna colour and the well-known fibrous character of chalcedony wherever that substance is most massive, as, for instance, within the chambers. The Foraminifera represented belong chiefly to the genera Rotalia, Globigerina, and Textularia. I may add that, as regards perfection in every minutest detail of shell-structure, these specimens greatly surpass in beauty those metamorphosed into glauconite, beautiful as they also undoubtedly are.

IX.-Notes on the Structure, Postembryonic Development, and Systematic Position of Scolopendrella. By J. WooDMason, Deputy Superintendent, Indian Museum, Calcutta.

THIS interesting and remarkable type of Tracheate Arthropoda was first made known to science in 1839 , in which year the distinguished zoologist Prof. P. Gervais brought to the notice of the Academy of Sciences at Paris some specimens of a small and fragile Myriopod which had been discovered in the vicinity of the French capital; and founded

* 'Comptes Rendus,' tome ix. p. 532 (1839). 